\title{
High-level resistance to aminoglycoside, vancomycin, and linezolid in enterococci strains
}

\author{
Gülçin Baldır ${ }^{1}$, Derya Öztürk Engin², Metin Küçükercan ${ }^{1}$, Asuman İnan², \\ Seniha Akçay ${ }^{1}$, Seyfi Özyürek ${ }^{2}$, Sebahat Aksaray ${ }^{1}$ \\ ${ }^{1}$ Department of Clinical Microbiology, Haydarpaşa Numune Training and Research Hospital, Istanbul, Turkey \\ ${ }^{2}$ Department of Infectious Diseases and Clinical Microbiology Haydarpaşa Numune Training and Research Hospital, Istanbul, \\ Turkey
}

\begin{abstract}
Objective: This study aimed to identify antibiotic susceptibility rates of enterococcal strains, and to compare the highlevel resistance to aminoglycosides (HLAR) in vancomycin-sensitive enterococcal species (VSE) and vancomycin-resistant enterococcal species (VRE).

Methods: The study included 100 VRE and 100 VSE strains recovered from the samples sent to laboratory from various departments of Haydarpaşa Numune Training and Research Hospital.

Results: All VRE strains were defined as Enterococcus faecium, although of the VSE strains, 53\% were identified to be as Enterococcus faecalis, 42\% E. faecium, 3\% Enterococcus durans, and 2\% Enterococcus avium. High-level resistance to vancomycin (MIC, $>256 \mu \mathrm{g} / \mathrm{ml}$ ) was determined in all VRE strains and when analyzing MIC values for teicoplanin, five strains were found to be moderately susceptible (MIC, $16 \mu \mathrm{g} / \mathrm{ml}$ ) and 95 strains were resistant (MIC, $>32 \mu \mathrm{g} / \mathrm{ml})$. Of the VRE strains, one was linezolid-resistant (MIC, $12 \mu \mathrm{g} / \mathrm{ml}$ ) and the other was intermediately susceptible (MIC, $4 \mu \mathrm{g} / \mathrm{ml})$ and remainders were evaluated to be susceptible (MIC, $<2 \mu \mathrm{g} / \mathrm{ml}$ ). In VRE strains, high-level gentamicin resistance (HLGR) was found to be $83 \%$ and high-level streptomycin resistance (HLSR) $89 \%$, association of HLSR with HLGR was $78 \%$. In VSE strains, HLGR was found to be $42 \%$ and, HLSR $48 \%$, the association of HLSR with HLGR was found to be $36 \%$. HLAR in VRE strains was found to be higher as compared with VSE strains ( $p$ <0.005).
\end{abstract}

Conclusion: Antimicrobial resistance is increasing in enterococci strains. Therefore a follow-up is required resistance pattern including both vancomycin resistance and HLAR. J Microbiol Infect Dis 2013; 3(3): 100-103

Key words: Enterococcus spp. , vancomycin, linezolid, aminoglycoside, resistance

\section{Enterokoklarda yüksek düzey aminoglikozid, vankomisin ve linezolid direnci}

\section{ÖZET}

Amaç: Bu çalışmada, enterokok suşlarının antibiyotik duyarlılık oranlarının saptanması, vankomisin duyarlı enterokok (VSE) ve vankomisin dirençli enterokok (VRE) suşlarındaki yüksek düzey aminoglikozid direncinin karşılaştırılması amaçlandı.

Yöntemler: Haydarpaşa Numune Eğitim ve Araştırma Hastanesi kliniklerinden gönderilen örneklerden, laboratuvarımızda izole edilen 100 adet VRE, 100 adet VSE suşu çalışma kapsamına alındı.

Bulgular: VRE suşlarının tümü Enterococcus faecium olarak tanımlanmış olup, VSE suşlarının ise \%53'ü Enterococcus faecalis, \%42'si E. faecium, \%3'ü Enterococcus durans, \%2'si Enterococcus avium olarak tespit edildi. VRE suşlarının tümünde yüksek düzey vankomisin direnci (MİK, $>256 \mu \mathrm{g} / \mathrm{ml}$ ) belirlendi, teikoplanin MİK değerleri incelendiğinde beş suş orta duyarlı (MİK, $16 \mu \mathrm{g} / \mathrm{ml}$ ), 95 suş dirençli (MİK, > $32 \mu \mathrm{g} / \mathrm{ml}$ ) olarak saptandı. VRE suşlarından biri linezolid dirençli (MİK, 12 $\mu \mathrm{g} / \mathrm{ml}$ ), biri ise orta duyarlı (MİK, $4 \mu \mathrm{g} / \mathrm{ml}$ ) olarak saptandı, diğer suşlar duyarlı (MİK, <2 $\mu \mathrm{g} / \mathrm{ml}$ ) olarak değerlendirildi. VRE suşlarında yüksek düzey gentamisin direnci (YDGD) \%83, yüksek düzey streptomisin direnci (YDSD) \%89, YDSD ve YDGD birlikteliği \%78 olarak bulundu. VSE suşlarında YDGD \%42, YDSD \%48, YDSD ve YDGD birlikteliği \%36 olarak tespit edilmiştir. VRE'lerde YDAD'nin VSE suşlarına göre yüksek olduğu belirlendi $(p<0,005)$.

Sonuç: Enterokok suşlarında antimikrobiyal direnç artmaktadır. Bu yüzden hem YDAD hem de vankomisin içeren direnç paternlerinin izlenmesi gereklidir.

Anahtar kelimeler: Enterococcus spp, vankomisin, linezolid, aminoglikozid, direnç

Correspondence: Derya Öztürk Engin,

Department of Infectious Diseases and Clinical Microbiology. Haydarpaşa Numune Training and Research Hospital, Istanbul, Turkey. Email: dr.deryaengin@gmail.com

Received: 13.11.2012 Accepted: 15.04.2013

Copyright (C Journal of Microbiology and Infectious Diseases 2013, All rights reserved 


\section{INTRODUCTION}

Enterococci found in the normal flora of the gastrointestinal system have recently become one of the major nosocomial pathogens. These bacteria were isolated from the urinary tract infections, intra-abdominal and pelvic infections as well as the causative agents of endocarditis, surgical wound infections, bacteremia, neonatal sepsis and rarely of meningitis. ${ }^{1,2}$ The drawback of the control and treatment of enterococcal infections is their intrinsic resistance to various antibiotics, their capabilities to develop new resistance and to live in the external environment for a long time.

The cell wall inhibitors such as penicillin, ampicillin, or vancomycin have been administered in combination with the aminoglycosides such as streptomycin and gentamicin in the treatment of serious infections caused by enterococci. ${ }^{3} \mathrm{~A}$ synergistic effect between the cell wall synthesis inhibitors and aminoglycosides disappears in the presence of high-level resistance to aminoglycoside and causes difficulties in the treatment of severe enterococcal infections. ${ }^{4}$

In this study we attempted to determine antibiotic sensitivity rates of vancomycin-sensitive enterococci (VSE) recovered from a variety of clinical material in Haydarpaşa Numune Training and Research Hospital, Istanbul, Turkey and antibiotic sensitivity rates in vancomycin-resistant enterococci (VRE) by the disk diffusion method and to identify minimum inhibitory concentration (MIC) values for vancomycin, teicoplanin and linezolid in VRE strains by means of E-test method and to compare a highlevel aminoglycoside resistance rates in VRE and VSE species.

\section{METHODS}

The study was performed in the laboratory of clinical microbiology of Haydarpaşa Numune Training and Research Hospital in 2008. The study was comprised of 200 Enterococcus species recovered from clinical materials and rectal swab samples. Stuart's transport medium was used in collecting rectal swab samples. The samples were cultivated onto bile esculin agar media containing $100 \mathrm{mg} / \mathrm{ml}$ azide and were incubated at $35^{\circ} \mathrm{C}$ for 24 hours. Black-colored colonies grown in bile-esculin agar were evaluated in terms of enterococci. The clinical materials were seeded in appropriate media and were incubated at $35{ }^{\circ} \mathrm{C}$ for 24 hours. The colonies suspected of enterococci were identified with Gram staining, catalase, PYR and, bacterial growth in $6.5 \% \mathrm{NaCl}$ and API 20 Strep (bioMerieux®, France).
The antimicrobial susceptibility tests were carried out in accordance with Clinical and Laboratory Standards Institute (CLSI) criteria applying the Kirby-Bauer disk diffusion method by means of penicillin, ampicillin, nitrofurantoin, tetracycline, ciprofloxacin, vancomycin, and teicoplanin discs (Oxoid Ltd, Basingstoke, UK) in all enterococcal species.5 Brain-heart infusion (BHI) agar containing $500 \mu \mathrm{g} /$ $\mathrm{ml}$ of gentamicin and BHI agar containing $2000 \mu \mathrm{g} /$ $\mathrm{ml}$ of streptomycin were used in an attempt to determine high-level gentamicin resistance (HLGR) and high-level streptomycin resistance (HLSR), respectively. The BHI agar containing $6 \mu \mathrm{g} / \mathrm{mL}$ of vancomycin was used to determine resistance to vancomycin. The MIC values for vancomycin, teicoplanin and linezolid in VRE strains were evaluated by the vancomycin agar screen test in accordance with the CLSI recommendations for the E-test method ( $A B$ Biodisk $囚$, Sweden). ${ }^{5}$

Beta-lactamase resistance was examined using nitrocefin disks. (Becton Dickinson $®$, USA). In our study, standard Enterococcus faecalis ATCC 29212 strain was used as the control. Chi-square test was used for statistical analysis. The results were evaluated at the significance level of $p<0.05$.

\section{RESULTS}

The study was comprised of 100 VRE and 100 VSE strains. All of VSE strains were isolated from the clinical materials. Of the VRE strains, 57 were collected from rectal swabs, 43 were collected from clinical materials respectively (Table 1). All VRE strains were defined as Enterococcus faecium and had high-level vancomycin resistance (MIC, >256 $\mu \mathrm{g} / \mathrm{ml})$. When the minimal inhibitory concentration of teicoplanin was examined in VRE strains, Five of 100 VRE strains were found to be moderately susceptible $(\mathrm{MIC},=16 \mu \mathrm{g} / \mathrm{ml}$ ) and 95 strains were determined to be resistant (MIC, $>32 \mu \mathrm{g} / \mathrm{ml}$ ) against teicoplanin. One of the VRE strains that had highlevel resistance to vancomycin and teicoplanin was linezolid-resistant $(\mathrm{MIC},=12 \mu \mathrm{g} / \mathrm{ml})$ and another was moderately susceptible (MIC, $=4 \mu \mathrm{g} / \mathrm{ml}$ ) the remainders were evaluated as susceptible (MIC, <2 $\mu \mathrm{g} / \mathrm{ml}$ ) to linezolid. Penicillin, ampicillin, tetracycline, teicoplanin, and nitrofurantoin resistance was found to be $100 \%$ and erythromycin and ciprofloxacin resistance was $99 \%$ and linezolid resistance was $2 \%$ in VRE strains using the disk diffusion method.

Of the 100 VSE strains, 51 were obtained from urine specimens. When VSE strains were examined on the basis of the isolation sites, most of $E$. faecalis were isolated from the urine, wound and bile culture samples, $(63 \%, 55 \%$, and $63 \%$ respectively) and 
most of $E$. faecium were isolated from blood culture samples $(56 \%)$. Of the 100 VSE strains, E. faecalis was responsible for $53 \%$, E. faecium $42 \%$, Enterococcus durans 3\%, and Enterococcus avium 2\%. Penicillin resistance was 33\%, ampicillin resistance was $24 \%$, erythromycin resistance was $92 \%$, tetracycline resistance was $78 \%$, ciprofloxacin resistance was $71 \%$, nitrofurantoin resistance was $27 \%$ in VSE strains by the disk-diffusion method.

Table 1. Distribution of enterococcus strains to isolation sites $(n=200)$

\begin{tabular}{lllll}
\hline & $\begin{array}{c}\text { Rectal } \\
\text { swap }\end{array}$ & Blood & Urine & $\begin{array}{l}\text { Other } \\
\text { samples }\end{array}$ \\
\hline $\begin{array}{l}\text { Vancomycin-resistant } \\
\text { enterococci }(n=100)\end{array}$ & 57 & 25 & 13 & 5 \\
$\begin{array}{c}\text { Vancomycin-sensitive } \\
\text { enterococci }(n=100)\end{array}$ & - & 25 & 51 & 24 \\
\hline
\end{tabular}

Gentamycin and streptomycin resistance in $E$. faecium and $E$. faecalis was established to be $20 \%$ and $14 \%$ in VSE strains respectively (Table 2 ). When VRE was compared to VSE, the rate of HLSR was detected to be $89 \%$ in VRE, while it was $48 \%$ in VSE; the rate of HLGR was noted to be $83 \%$ in VRE and it was $42 \%$ in VSE. The association of HLGR with HLSR namely high-level aminoglycoside resistance (HLAR) was $78 \%$ in VRE, and $36 \%$ in VSE strains respectively. HLAR was found to be significantly higher in VRE strains than those in VSE strains $(p<0.005$; Table 3$)$.

Table 2. Distribution of high-level aminoglycoside resistance (HLAR) among vancomycin-sensitive enterococci $(n=100)$

\begin{tabular}{|c|c|c|c|c|}
\hline & E. faecalis & E. faecium & E. avium & E. durans \\
\hline Gen R-Strep R & 14 & 20 & 1 & 1 \\
\hline Gen S-Strep S & 31 & 12 & 1 & 2 \\
\hline Gen R-Strep S & 1 & 5 & - & - \\
\hline Gen S-Strep R & 7 & 5 & - & - \\
\hline
\end{tabular}

Gen R=gentamicin resistant; Strep R=streptomycin resistant; Gen $S=$ gentamicin sensitive; Strep $S=$ streptomycin sensitive.

Table 3. Comparison of high-level aminoglycoside resistance (HLAR) between vancomycin resistant enterococci (VRE) and vancomycin-sensitive enterococci (VSE) $(n=200)$

\begin{tabular}{lccc}
\hline Variable & VRE $(n=100)$ & VSE $(n=100)$ & $p$-value \\
\hline Gen R-Strep R & 78 & 36 & $<0.0001$ \\
Gen S-Strep S & 6 & 46 & $<0.0001$ \\
Gen R-Strep S & 5 & 6 & 1.0 \\
Gen S-Strep R & 11 & 12 & 1.0 \\
\hline
\end{tabular}

Gen R=gentamicin resistant; Strep R=streptomycin resistant; Gen $\mathrm{S}=$ gentamicin sensitive; Strep $\mathrm{S}=$ streptomycin sensitive.

\section{DISCUSSION}

Ampicillin resistance in enterococci may be caused either by change in penicillin-binding proteins or rarely by production of a beta-lactamase enzyme. VRE have multiple antibiotic resistance comprising the aminoglycosides (including high level of resistance) and ampicillin. ${ }^{6}$ The penicillin and ampicillin resistant VSE strains were determined to be $33 \%$, $23 \%$ and ampicillin resistant VRE strains to be $100 \%$ by disk diffusion method in our study. In two different studies penicillin resistance was noted to be $25.7 \%$ and $28.8 \%$ and ampicillin resistance was noted to be $18.6 \%$ and $28.8 \%{ }^{3,7}$ The other study on VRE strains ampicillin resistance consistent with our study. ${ }^{8}$

Glycopeptide resistance in enterococci is one of the most important challenges. VRE takes place among the important nosocomial pathogens, in that the treatment options are limited, it easily spreads in the hospital setting and it is likely to transfer vancomycin resistance to other pathogens. VRE is known to spread in the hospital setting through contaminated hands and surfaces. Centers for Disease Control and Prevention (CDC) suggests that aggressive infection control be implemented and that hospital staff conform to the isolation precautions in order to control and prevent VRE infection. ${ }^{9}$ VRE was first reported in 1998 in our country, followed by a multi-hospital VRE outbreaks. ${ }^{10-12}$ The first VRE strain was isolated in our hospital in 2005. After the establishment of VRE, contact isolation was implemented for the patients and rectal swab samples were collected from clinics where VRE was detected particularly in the intensive care unit and screenings were performed. ${ }^{13}$

E. faecalis (80-90\%) and E. faecium (10-15\%) in enterococci were the species that were clinically isolated highest. ${ }^{3}$ Although E. faecalis was frequently isolated as infectious agents, vancomycin resistance was detected at a higher rate in $E$. faecium. ${ }^{14,15}$ We detected all VRE strains as $E$. faecium and $E$. faecalis was the most in VSE strains.

HLAR is caused by the secretions of various aminoglycoside-modifying enzymes. ${ }^{16}$ The rate of HLAR in VRE was determined to be higher as compared to that of VSE strains. In the study by Mihajlovic et al. ${ }^{17}$ on VRE strains HLGR was identified to be $87.6 \%$, and HLSR to be $95.2 \%$, while in the study by Yildirim et al. ${ }^{18} \mathrm{HLSR}$ and HLGR in VSE strains were determined to be $19.8 \%, 9.9 \%$, respectively. The rate of HLAR in VRE strains was significantly higher than VSE strains in our study. Vancomycin resistance in enterococci as well as 
HLAR poses difficulty in the treatment of especially severe infections.

HLAR in E. faecium strains appears to be higher than that of $E$. faecalis. In the study by Mendiratta et al. ${ }^{16}$ of 150 of enterococcal species, 69 (49\%) had high-level resistance to gentamicin and/or streptomycin. In their study, HLGR (95.5\%) was significantly higher in $E$. faecium species as compared with E. faecalis species (37.5\%). A study performed in Turkey found that $52 \%$ of E. faecium were HLGR and $74 \%$ were HLSR and $20 \%$ of $E$. faecalis species were HLGR, and $31 \%$ were HLSR. ${ }^{15}$ In that study no vancomycin resistance was also found in $E$. faecium and $E$. faecalis species. We detected $E$. faecium to be $57.7 \%$ in VSE strains where a HLAR was detected. Our results were regarded as compatible with other studies.

Treatment choice in VRE is limited. Linezolid, a ribosomal protein synthesis inhibitor, was approved by FDA in the USA for use in some VRE infections. ${ }^{19}$ However, enterococci may be resistant to linezolid, which reduces the treatment options. In our study, one of the VRE species was linezolid-resistant and, the other was identified as moderately sensitive. In our hospital, following isolation of linezolid-resistant enterococci not only were training programs on infection control measures intensified but also policies regarding antibiotic use were revised. It is considered that, although there has been no linezolid resistance after taking these measures, precaution for infection control is necessary to ensure continuity.

The limitation of our study is that no molecular methods have been used. It is of significance to identify the type of vancomycin resistance to enterococci in treatment. The strains containing vanA and vanB genes carry a high level of resistance to vancomycin, while those carrying VanC gene show a low level of resistance to vancomycin. The strains with vanA gene are resistant to teicoplanin as well as vancomycin while those with vanB gene are susceptible to teicoplanin. It is likely to identify microorganisms by molecular methods and to determine the relationship between them. Thus, molecular methods yield results earlier as compared with routine methods, allowing isolation measures in colonized patients without delay. However, molecular techniques are associated with increased cost, limiting its use.

Being familiar with the characteristics of resistance in enterococci, the accurate determination of the results of antibiotic susceptibility will provide the appropriate treatment of infections produced by these pathogens. VRE continues to pose a threat to our hospital. A higher resistance rate to other antibiotics in VRE strains, particularly to aminoglycosides is also troublesome. Limited treatment options for serious infections caused by resistant enterococci make it necessary to intensify infection control procedures and a follow-up of resistance.

\section{REFERENCES}

1. Sood S, Malhotra M, Das BK, Kapil A. Enterococcal infections \& antimicrobial resistance. Indian J Med Res 2008;128:111-121.

2. Fisher K, Phillips C. The ecology, epidemiology and virulence of Enterococcus. Microbiology 2009;155:1749-1757.

3. Adhikari L. High-level aminoglycoside resistance and reduced susceptibility to vancomycin in nosocomial enterococci. J Glob Infect Dis 2010;2:231-235.

4. Arias CA, Murray BE. Enterococcus species, Steptococcus bovis group, and Leuconostoc species. In: Mandell GL, Bennett JE, Dolin R, editors. Douglas and Bennett's Principles and Practice of Infectious Disease 7th ed. Philadelphia, Churchill Livingstone; 2010:2643-2653.

5. Clinical and Laboratory Standards Institute Performance Standards for Antimicrobial Susceptibility Testing. Seventeenth Informational Supplement. M100-S17, 2007. CLSI, Wayne, PA.

6. Shouten MA, Hoogkamp-Korstanje JA, Meis JF, Voss A; European VRE Study Group. Prevalence of vancomycin-resistant enterococci in Europe. Eur J Clin Microbiol Infect Dis 2000;19:816-822.

7. Moaddab SR, Rafi A. Prevalence of vancomycin and high level aminoglycoside resistant enterococci among high-risk patients. Southeast Asian J Trop Med Public Health. 2003; 34:849-854.

8. Cuellar-Rodriguez J, Galindo-Fraga A, Guevara V, et al. Vancomycin-resistant enterococci, Mexico City. Emerg Infect Dis 2007;13:798-799.

9. Centers for Disease Control and Prevention. Recommendations for preventing spread of vancomycin resistance. Infect Control Hosp Epidemiol 1995;16:105-113.

10. Vural T, Sekercioglu AO, Ogunc D, et al. Vancomycin resistant Enterococcus casselifavus isolate. Ankem Derg 1998;12:113.

11. Yazgi H, Ertek M, Erol S, Ayyıldız A. A comparison of high-level aminoglycoside resistance in vancomycin-sensitive and vancomycin-resistant Enterococcus species. J Int Med Res 2002; 30:529-534.

12. Karagoz G, Kadanalı A, Ak O, Ozer S. Vancomycin-resistant enterococci rectal colonization in an intensive care unit. A report from Turkey. Am J Infect Control 2012;40:83-84.

13. Cicekler-Tok N, Ozturk Engin D, Tok B, et al. Vancomycin-resistant enterococci (VRE) scan in rectal swab samples of a patient admitted to the department of Anesthesiology and Reanimation. The Medical Journal of Haydarpasa Numune Training and Research Hospital 2007;48:38-41.

14. Kacmaz B, Aksoy A. Antimicrobial resistance of enterococci in Turkey. Int J Antimicrob Agents 2005; 25:535-538.

15. Oncu S, Punar M, Eraksoy H. Susceptibility patterns of enterococci causing infections. Tohoku J Exp Med 2004; 202:23-29.

16. Mendiratta DK, Kaur H, Deotale V, et al. Status of high level aminoglycoside resistant Enterococcus faecium and Enterococcus feacalis in a rural hospital of Central India. Indian J Med Microbiol 2008;26:369-371.

17. Mihajlovic Ukropina M, Jelesic Z, Gusman V, Milosavljevic B. Frequency of vancomycin-resistant enterococci isolated from blood cultures from 2008 to 2010. Med Pregl 2011;64:481-485.

18. Yildirim M, Sencan I, Ozdemir D, et al. Investigation of vancomycin and high-level aminoglycoside resistant enterococus carriage and the risk factors related to resistance in hospitalized patients. Mikrobiol Bult 2007;41:271-277.

19. Arias CA, Contreras GA, Murray BE. Management of multidrug-resistant enterococcal infections. Clin Microbiol Infect 2010;16:555-562. 